\title{
REPRESENTASI DOMINASI PENGUASA DALAM NOVEL PASAR KARYA KUNTOWIJOYO
}

\author{
Wiwin Kurnia Widyanti \\ Prodi Pendidikan Bahasa dan Sastra Indonesia, Fakultas Keguruan dan Ilmu Pendidkan, \\ Universitas Muhammadyah Malang \\ Wiwinkurnia0131@gmail.com
}

\section{ABSTRAK}

Penelitian ini bertujuan untuk menggambarkan secara mendalam aktualisasi diri dari tokoh yang ingin mencapai sebuah kekuasaan dengan cara menguasai sebuah pasar. Masalah yang difokuskan dalam penelitianm ini adalah bagaimana tokoh memimpin masyarakat terhadap lingkungan dan perkembangannya yang tergambar dalam cerita kehidupan pasar Gemolong secara sosial dan politik. Kuntowijoyo ini adalah menggunakan metode kualitatif deskriptif dengan pendekatan sosiologi sastra. Metode ini digunakan sebagai pemecahan masalah yang dilakukan dengan menggambarkan suatu keadaan objek dan subjek penelitian. Dengan menggunakan teori sosiologi sastra yang terbagi atas beberapa komponen diantaranya komponen sosial, masyarakat, dan politik, tulisan ini menganalisis proses pemertahanan kepemimpinan tokoh terhadap lingkungan dan masyarakat. Hasil penelitian membuktikan/menunjukkan bahwa tokoh memimpin wilayah pasar dengan cara melakukan strategi kepemimpinannya yang berbeda dan menciptakan salah satu bentuk pertahanan dari kepemimpinan tokoh.

Kata kunci: Sosial, Politik, Penguasa

\section{PENDAHULUAN}

Karya sastra merupakan wadah seni menampilkan keindahan lewat penggunaan bahasa yang menarik, bervariasi, dan berimajinasi. Sosiologi sastra merupakan ilmu yang membahas beberapa faktor sosial yang dapat pembangun sastra. Sosiologi sastra jelas ilmu tentang interdisiplin, yang memperhatikan fakta estetis dan fakta kemanusiaan. Sosiologi mencoba mempelajari lembaga-lembaga sosial dan segala masalah ekonomi, politik, agama, dan lain-lain yang kesemuanya itu merupakan struktur sosial kita untuk mendapatkan gambaran mengenai cara-cara manusia menyesuaikan diri dengan lingkungan sosial.

Politik kesusastraan meliputi struktur sosial. Dalam kehidupan berpolitik, untuk mencapai tujuan selalu berhadapan 
Wiwin Kurnia Widyanti: Represanti Dominasi Penguas dalam Novel PasarKarya Kuntowijoyo

Website : https://jurnal.umj.ac.id/index.php/penaliterasiEmail : penaliterasi@umj.ac.id

dengan konflik yang timbul akibat pergesekan dengan kalangan internal maupun eksternal.Istilah dominasi memiliki pengertian umum yaitu tentang bagaimana pemanfaatan keadaan untuk kepentingan individu, tanpa mempertimbangkan khalayak ramai.itu, pendahuluan berisi landasan teori yang digunakan untuk menganalisis objek yang dikaji.

Adapun hal-hal yang mendasari mengenai penelitian ini yaitu mengenai sosiologi sastra dan bagaimana keterkaitan antara sastra dengan politik. Sosiologi studi mengenai lembaga sosial dan proses-proses sosial. Studi ini membahas mengenai bagaimana cara kerjanya dan mengapa masyarakat itu bertahan hidup. Melalui penelitian yang ketat dan akurat mengenai lembaga-lembaga sosial, keagamaan, perekonomi, politik, dan keluarga yang secara bersama-sama membentuk struktur sosial, memperoleh gambaran mengenai cara-cara manusia menyesuaikan dirinya dan ditentukan oleh masyarakat-masyarakat tertentu, gambaran mengenai mekanisme sosialisasi, proses belajar secara kultural, yang dengannya individu menerima peranan-peranan tertentu dalam struktur sosial itu.

Pada masalah perubahan dan pembaruan, sosiologi menyumbangka pengertian akan adanya perubahan dan pembaruan dalam masyarakat. Apabila dalam masyarakat timbul golongangolongan atau kelompok-kelompok untuk memajukan kepentingan baru, maka nilai kebudayaan masyarakat secara keseluruhan akan menunjukkan perubahan dalam pola pada kehidupan politik. Sosiologi menggambarkan bahwa pada masyarakat yang sederhana maupun yang kompleks senantiasa terdapat kecenderungan untuk timbulnya proses, pengaturan, atau pola- pola pengendalian tertentu yang formal maupun yang tidak formal.

Sosiologi juga menganalisis proses politik dalam referensi kerangka sosiologis, berorientasi adalah perhatian utamanya dengan dinamika perilaku politik, sebagaimana konflik, mobilitas sosial, pembentukan opini publik, menggeser kekuasaan dari berbagai kelompok, dan segala proses yang mempengaruhi perilaku politik.

Novel Pasar yang ditulis Kuntowijoyo tahun 1971 merupakan salah satu novel yang mencoba mengangkat realitas kehidupan masyarakat pada masa itu, khususnya masyarakat Jawa.Novel ini menggambarkan kondisi sosial masyarakatnya.Cerita dalam novel Pasar sesungguhnya sangat sederhana.Latar cerita adalah masyarakat Jawa, yang diwakili oleh sebuah kecamatan, yaitu Kecamatan Gemolong. Perseteruan antar tokoh terjadi ketika ada dua tokoh yang berseteru karena memiliki hasrat untuk memiliki wilayah kekuasaan yaitu, pasar. Keduanya saling menunjukkan strategi yang dimiliki.

Novel Pasar berkisah tentang Pak Mantri Pasar, sosok priyayi yang menjadi panutan di sebuah pasar kecamatan di pelosok desa di Jawa.Pak Mantri dipandang priyayi bukan karena keturunan, tetapi lebih karena kepribadiannya.Semua yang baikbaik dari orang Jawa ada padanya yaitu hidup jujur, setia, sopan santun, dan tahu diri. Dari mulutnya, sering muncul petuahpetuah khas yang merakyat sekaligus mendalam maknanya.Sikap politik kepemimpinan tokoh ini membuatnya disegani masyarakat.Berkat kepandaian ilmunya, juga tingginya budi pekertinya, Pak Mantri Pasar dianggap tidak hanya sebagai mantri pasar, tetapi dia adalah 
Wiwin Kurnia Widyanti: Represanti Dominasi Penguas dalam Novel PasarKarya Kuntowijoyo

Website : https://jurnal.umj.ac.id/index.php/penaliterasiEmail : penaliterasi@umj.ac.id

panutan. Sosoknya melambangkan kaum priyayi dengan watak istimewa sehingga layak diistimewakan. Tidak sedikit juga orang yang tidak menyukai tokoh Pak Mantri. Diantaranya salah seorang yang tidak menyukainya tersebut terus melakukan berbagai macam cara untuk menjatuhkan tokoh Pak Mantri tersebut.

Identifikasi Masalah dalam penelitian ini, yaitu novel Pasar karya Kuntowijoyo kemungkinan berisi nilai politik sosial.Persoalan yang diangkat adalah tokoh yang ingin menguasai sebuah wilayah pasar yang bertujuan untuk menjadikannya orang terpandang.Tujuan penelitian yaitu merepresentasikan aspekaspek politik kepemimpinan dari masingmasing tokoh yang terkandung dalam novel Pasar karya Kuntowijoyo.

\section{METODE PENELITIAN}

Metode yang digunakan untuk menganalisis kajian politik dan sosial pada novel Pasar karyaKuntowijoyo ini adalah menggunakan metode kualitatif deskriptif dengan pendekatan sosiologi sastra. Metode ini membutuhkan kekuatan analisis yang lebih mendalam, terperinci namun meluas, maka kekuatan akal adalah satu-satunya sumber kemampuan analisis dalam seluruh proses penelitian. Penelitian kualitatif yang dilakukan diharapkan dapat membantu memperoleh informasi yang akurat dalam penelitian terhadap penelitian tentang kajian aspek politik melalui pendekatan sosiologis sastra dalam novel Pasar karya Kuntowijoyo. Metode kualitatif juga memberikan perhatian terhadap data alamiah, data dalam hubungannya dengan konteks keberadaanya. Jika dilibatkan dalam karya sastra maka hubungannya akan dilibatkan dalam pengarang, lingkungan sosial, termasuk unsur-unsur kebudayaan pada umumnya. Dalam ilmu sosial sumber datanya adalah masyarakat, yaitu mengenai tindakan-tindakan, sedangkan dalam ilmu sastra yang terlibat adalah karya, naskah dan data penelitiannya, bukti nyata dalam bentuk data formal yaitu kata-kata, kalimat, dan wacana.

Subjek penelitian penulis adalah novel berjudul Pasar karya Kuntowijoyo.cetakan ke-1 diterbitkan oleh DIVA Press Yogyakarta, dengan tebal 375 halaman. Objek penelitian ini adalah aspek politik dan aspek sosial melalui pendekatan sosiologi sastra tokoh utama dan wilayah kekuasaan yang terdapat dalam novel Pasar karya Kuntowijoyo. Teknik analisis data yang digunakan teknik menganalisis isi karena memanfaatkan seperangkat prosedur untuk menarik kesimpulan yang lebih akurat dari sebuah buku atau dokumen (Weber dalam Haryani, 2009:30) pada novel Pasasr karya Kuntowijoyo ini yang digunakan adalah pendekatan analisis sosiologi sastra, yang meliputi aspek kepemimpinan, aspek politik, aspek etika, aspek sosial ekonomi. Menganalisis data yang telah diklasifikasikan dari membaca dan mencocokkan dari kutipan

\section{HASIL DAN PEMBAHASAN}

Telah disebutkan di awal tulisan bahwa Perseteruan antar tokoh terjadi ketika ada dua tokoh yang berseteru karena memiliki hasrat untuk memiliki wilayah kekuasaan yaitu pasar. Keduanya saling menunjukkan strategi yang dimiliki.Tentang Pak Mantri Pasar, sosok priyayi yang menjadi panutan di sebuah pasar kecamatan di pelosok desa di Jawa.Tetapi tidak sedikit juga orang yang tidak menyukai tokoh Pak Mantri. Diantaranya salah seorang yang tidak 
Wiwin Kurnia Widyanti: Represanti Dominasi Penguas dalam Novel PasarKarya Kuntowijoyo

Website : https://jurnal.umj.ac.id/index.php/penaliterasiEmail : penaliterasi@umj.ac.id

menyukainya tersebut terus melakukan berbagai macam cara untuk menjatuhkan tokoh Pak Mantri tersebut.Pada pembahasan ini, terdapat aspek yang mendasari penelitian politik kepemimpinan dalam novel Pasar ini, yaitu: 1) aspek kepemimpinan; 2) aspek perekonomian; 3) aspek etika; 4) aspek politik

\section{Dominasi Penguasa berdasarkan Aspek Kepemimpinan Tokoh}

Persoalan kepemimpinan yang tertuang dalam novel Pasar salah satunya yaitu kepemimpinan karena berdasarkan sikap dan strategi kepemimpinan seorang tokoh yang dimunculkan akan memudahkan masyarakat untuk menilai apakah sosok tersebut layak untuk menjadi pemimpin atau tidak. Dalam novel Pasar initokoh memimpin dengan mengemban tugasnya sangat tegas, tetapi saat muncul permasalahan yang berkaitan dengan hewan peliharaannya ini, tokoh mendadak menjadi egois, tidak ada toleransi.

"siapa yang berani tidak membayar uang pasar?

Siapa saja yang berani membunuh hewan

peliharaanku?Katakan

padaku Jo."(Pasar:287)

Berdasarkan kutipan di atas dapat disimpulkan bahwa dalam menjalankan pasar ini tokoh juga membuat aturanaturan yang harus dipatuhi oleh warga.Dengan sikapnya tersebut membuat warga menjadi takut dan terus mematuhi perintah tokoh pemimpin.Hal tersebut menjadikan kepemimpinan tokoh Pak Mantri mengakibatkan dampak negatif dari cara tokoh memimpin wilayahnya. Sikap keegoisan pemimpin yaitu memikirkan kepentingan peliharaannya semata sangatlah berpengaruh untuk kekuasaannya karena masyarakat gemolong tersebut akan berpikir seperti apa pemimpin yang akan dipilihnya. Dampak yang terjadi ialah kerugian pada proses perdagangan warga. Hal tersebut terdapat pada cuplikan dibawah ini.

"he, aku minta ganti rugi. Gara-

gara pak mantri, semua

daganganku habis diambil oleh

pelaku yang tidak tahu diri

itu"(Pasar:292)

Selain terkait masalah sikap tokoh utama yang kurang baik, terdapat pula masalah tentang sikap tokoh kasan Ngali yang kasar dan selalu memerintah masyarakatnya karena tokoh tersebut merasa sangat benar. Sikap Kasar yang ditunjukkan oleh tokoh tersebut sangat tidak patut untuk seorang tokoh yang memiliki jabatan ataupun seorang panutan untuk orang lain. Sikap kasar yang terlihat pada kutipan berikut:

"Tidak usah diurus siapa yang berbuat ini.Tugas kalian adalah, usir semua orang dari pekarangan.Tutup pintu dan jangan perbolehkan siapapun masuk ke wilayah ini. Kerjakan dan jangan banyak tanya, aku benci pertanyaan!"Mereka pun bubar dan pedagang yang sedang membeber dagangannya pun diusir.Dalam hal ini, kepemimpinan Kasan Ngali terlihat begitu sangat mengerikan dan kasar.( Pasar:255) 
Wiwin Kurnia Widyanti: Represanti Dominasi Penguas dalam Novel PasarKarya Kuntowijoyo

Website : https://jurnal.umj.ac.id/index.php/penaliterasiEmail : penaliterasi@umj.ac.id

Dari kutipan di atas terdapat sikap kepemimpinan tokoh pada saat mengerahkan seluruh anggotanya untuk bertindak atas permasalahan yang tengah terjadi dalam wilayah pasarnya. Tokoh tampak sangat kasar dan mengerahkan anggotanya tidak pada hal yang baik.Saat tokoh Kasan Ngali memberi perintah, tidak ada satupun dari mereka yang mampu membantah.Secara tidak langsung dari sikap yang ditunjukkan tersebut mengurangi empati dari warga kepada pemimpinnya.

\section{Dominasi Penguasa Berdasarkan Aspek Perekonomian Wilayah}

Persoalan perekonomian merupakan salah satu yang menjadi hambatan para tokoh pemimpin. Berdasarkan sikap tokoh pemimpin dalam Novel Pasar ini dapat dijelaskan bagaimana keadaan perekonomian sosial yang dihadapi masyarakat.Warga mengalami kerugian akibat ulah pak mantri yang terbilang egois tersebut.

"aku tidak mau membayar karcis ini, gara-gara burung itu tidak ada pemasukan, semua habis diambil oleh mahluk tidak tau diri itu" (Pasar:33)

Berdasarkan kutipan di atas terlihat beberapa warga pasar juga ada yang protes akan hal yang sama, yaitu burung peliharaan tokoh Pak Mantri yang lambat laun merugikan para pedagang. Permasalahan yang yang terjadi ialah hewan peliharaan tersebut berkubang dalam adonan masakan yang dimiliki salah satu pedagang.Sehingga hasil dagangan mereka tidak laku.Pedagang merasa dirugikan dengan hewan

peliharaan tokoh Pak Mantri, karena dagangan mereka selalu saja habis dimakan oleh hewan tersebut.Hal tersebut juga menjadikan sisi buruk dari kepemimpinan tokoh Pak Mantri yaitu ingin menang sendiri jika sudah berkaitan dengan hewan peliharaannya, tanpa memikirkan kerugian yang terjadi pada warganya Sehingga warga pun tak menampik hal tersebut mempengaruhi nilai kepemimpinannya. Hal ini juga bepengaruh pada bank kredit milik tokoh Zaitun, salah satunya yaitu penurunan pendapatan pada bank kredit. Terlihat pada saat tokoh Zaitun menawarkan tabungan banknya beberapa warga menolak.Hal ini disebabkan hilangnya nasabah itu, dikarenakan nasabah tersebut merasa dirugikan oleh hewan peliharaan( dijelaskan burungnya mengapa)Pak Mantri. Pembahasan ini terdapat pada kutipan sebagai berikut.

"Menabung?Ah,Untungya saja
habisa dimakan burung dara!"
Burung dara! alamat yang tidak
baik." "Akhir-akhir ini
pemasukan di bank selalu
menurun.Apa yang menjadi
penyebabnya? Apakah benar
yang diberitakan oleh warga
bahwa Pak Mantri
penyebabnya"(Pasar:28)

Berdasarkan pembahasan diatas warga pasar menilai tokoh pemimpin dengan sikapnya yang bisa dikatakan egois, karena hanya mengikuti keinginannya sendiri tanpa memperdulikan dampak negatif yang terjadi pada masyarakatnya.Sehingga para pedagang menuiaikan pandangan 
Wiwin Kurnia Widyanti: Represanti Dominasi Penguas dalam Novel PasarKarya Kuntowijoyo

Website : https://jurnal.umj.ac.id/index.php/penaliterasiEmail : penaliterasi@umj.ac.id

penilaian kepemimpinan yang tidak baik melanggar beberapa peraturan yang dibuat oleh tokoh tersebut karena warga merasa kerugian yang sangat besar. Warga juga tidak menampik jika ada seorang tokoh yang menyediakan ruang yang cukup dan menguntungkan hasil dagangan dan warga beralih pada tokoh Kasan Ngali yang tidak lainsalah satu tokoh yang ingin menguasai pasar.

\section{Dominasi Penguasa berdasarkan Aspek Etika yang dilakukan oleh tokoh}

Persoalan selanjutnya yang terdapat pada novel Pasar tidak hanya terkait permasalahan perekonomian yang dihadapi oleh warga saja.Tokoh secara tidak langsung juga menonjolkan etika kepemimpinannya secara individual yang terdapat pada kutipan di bawah ini.

"saat dimarahi pak mantri tidak terlalu sakit hati. Mengadu salah tidak mengadu salah. Jika ada orang-orang pasar yang menyalahkannya, maka pak manti bertindak sebaliknya. Orang pasar takkan berani berhadapan muka dengannya"(Pasar:27)

Berdasarkan uraian diatas etika yang mencerminkan seorang pemimpin salah satunya, mudah menerima kritik dari orang lain, kesabaran merupakan salah satu etika yang baik dalam berpemimpin. Dalam konteks ini dijelaskan bagaimana cara masyarakat berprilaku, tetapi pak mantri tidak bersikap kepada warganya layaknya seorang pemimpin. Tetapi dalam memimpin Pak Mantri ini terkadang membuat sakit hati, walaupun memiliki banyak kekurangan warga tetap empati kepada tokoh Pak Mantri dengan menutupinya dengan kelebihan yang dimiliki tokoh tersebut, karena mampu mengatasi permasalahan yang dialaminya.

Adapun kebencian tokohutama kepada Kasan Ngali, tokoh lain yang juga ingin menguasai wilayah pasar tersebut. Dalam novel Pasar ini kesalahan tokoh Kasan Ngali adalah membuka pasar tidak resmi di pekarangan rumahnya sehingga menimbulkan kesulitan bagi tokoh Pak Mantri dalam memenuhi target pendapatan dari karcis pasar resmi. Hal tersebut membuat tokoh Pak Mantri mengumpat, seharusnya juga terdapat pada kutipan dibawah ini.

"Pasar baru Kasan Ngali telah mengacaukan pikirannya (Pak Mantri, pen.)benar. Keparat!" (Pasar:251)

Selain persoalan diatas, terdapat konflik lain yang mencerminkan etika tokohtokoh kasan ngali yaitu tak jarang suka mengutuk orang. Jika ia tidak mendapatkan keberhasilan atas apa yang diinginkan, maka ia akan mencoba memaksakan keadaan dan mengalaukan segala cara.Hal tersebut merupakan sikap yang tidak boleh dimiliki oleh seorang pemimpin.

"Hentikan anak-anak itu !" Ia membentak seorang buruh. "He larang saja mereka menangkapi itu! Kau, Kau! Pergi semua. Diajarkan apa kalian disekolah? Siapa ayahnya! Usir anak-anak itu segera!"(Pasar:26)

Berdasarkan kutipan diatas tokoh terkenal dengan kesombongannya dan keangkuhannya.Ia juga tidak pandai bagaimana cara mengkondisikan disetiap suasana.Sehingga secara tidak langsung pandangan kepada tokoh pemimpin kasan 
Wiwin Kurnia Widyanti: Represanti Dominasi Penguas dalam Novel PasarKarya Kuntowijoyo

Website : https://jurnal.umj.ac.id/index.php/penaliterasiEmail : penaliterasi@umj.ac.id

ngali dianggap tidak memiliki etika yang baik.

\section{Dominasi Penguasa berdasarkan Aspek Politik dalam memimpin Wilayah}

Selain permasalahan etika dalam memimpin wilayah pasar, terdapat aspek politik yang menjadi komponen penting dalam memimpin sebuah wilayah. Dalam novel pasar masing-masing tokoh memiliki cara yang berbeda dalam berpolitik dagang dan kepemimpinan. Tokoh kasan ngali yang memanfaatkan keadaan yang genting.Tokoh Kasan Ngali, orang kaya pemilik toko di depan pasar, memanfaatkan situasi itu dengan mendirikan pasar baru dan Bank Kredit di pekarangannya. Pasar tokoh Kasan Ngali pun tidak ditarik karcis. Hal ini akhirnya membuat para pedagang pasar pindah ke pasar Kasan Ngali.Strategi yang dimiliki oleh tokoh dapatterlihat saat tokoh Pak Mantri mulai membatin yang terdapat pada cuplikan berikut.

"Banyak orang berkerumunan di toko kasan ngali.Dipojok itu telah dibuat semacam loket baru.Bangunan dari kayu. Di situ tertulis sebagai kantor bank kredit. Kasan Ngali mengawasi jalannya pekerjaan, memberi perintah pada pegawai.Menyediakan kredit dengan pembayaran cicilan dan bunga ringan." (Pasar:185)

Selain uraian konflik diatas kemudian berkembang dengan melibatkan tokoh-tokoh lain (Camat, Kasan Ngali) dalam lingkup masalah yang lebih luas, yang menyangkut masalah sosial ekonomi, politik, dan budaya itu sendiri. Tetapi karena kegeraman tokoh Pak Mantri justru membuatnya mawas diri.Pak Mantri mencoba menyelesaikan persoalan dengan dengan baik dan dewasa, meskipun tak seutuhnya sikap tokoh Pak Mantri itu dipandang baik oleh warga.Tokoh mampu mengolah emosionalnya, sehingga mampu menunjukkan bahwa tokoh Pak Mantri mampu menyelesaikan persoalan dan dapat menjadi pemenang dalam konflik tersebut bersama anak buahnya. Hal tersebut terdapat pada kutipan berikut.

"Sebentar lagi engkau akan jadi orang lain, Nak. Setiap orang harus sadar akan kedudukannya. Tukang gerobag boleh tertawa keras. Tetapi seorang kepala pasar tidak. Seorang guru tidak. Lagi pula yang penting, ingatlah bahwa kau orang Jawa. Ketika engkau gembira, ingatlah pada suatu kali kau akan mendapat kesusahan. Apalagi menertawakan nasib buruk orang lain, Nak. Jangan, sekalikali jangan. Orang yang berpangkat harus berbuat baik, suka menolong. Kalau ada yang kesusahan, harus bisa membantu. Jangan malah menertawakan. Kalau tidak bisa membantu, menyesallah. Dan berjanjilah suatu kali kau akan membantu. Sebaliknya ikutlah berduka cita atas kemalangan orang lain. Engkau boleh tertawa apabila saudaramu beroleh kesukaan. Bersusahlah bersama orang yang susah, bergembiralah bersama orang yang bergembira. Renungkanlah, Nak."(Pasar:281)

Berdasarkan kutipan diatas strategi politik kepemimpinannya ini terlihat mampu mengendalikan segala permasalahan yang terjadi di wilayah pasar tersebut.Tokoh Pak 
Wiwin Kurnia Widyanti: Represanti Dominasi Penguas dalam Novel PasarKarya Kuntowijoyo

Website : https://jurnal.umj.ac.id/index.php/penaliterasiEmail : penaliterasi@umj.ac.id

Mantri masih memegang sikap budi

luhurnya.Tokoh Pak Mantri selalu berusaha menjalankan hidupnya dengan segala keyakinan dan sifat-sifat yang dimiliki oleh Tuhan.Tokoh Pak Mantri mengutamakan kejujuran dan kesetiaan dalam menjalankan tugasnya. Tokoh juga tidak mau berprasangka buruk pada orang lain, karena yang salah bukan orangnya, tetapi perbuatannya. Terbukti ketika Kasan Ngali jatuh, tokoh tidak menunjukkan rasa gembira. Bagi tokoh Pak Mantri, tidak baik menertawakan nasib buruk orang lain.Meskipun sangat jelas bahwa tokoh Kasan Ngali selama ini memusuhinya.

\section{KESIMPULAN}

Novel Pasar mengetengahkan perubahan sosial masyarakat di sebuah kecamatan. Adanya perubahan sosial inilah yang mengakibatkan terjadinya konflik di antara tokoh-tokohnya. Konflik tersebut antara lain dialami tokoh-tokoh yang mewakili kelas priyayi agraris (Pak Mantri), wong cilik (Paijo), dan pedagang kapitalis (Kasan Ngali). Permasalahan utama yang diangkat oleh Kuntowijoyo yaitu konflik sosial yang dialami oleh tokoh dan dikemas dengan bahasa yang segar. Jalinan ceritanya diawali dengan mengetengahkan tokoh Pak Mantri yang menjadi tokoh utama dalam novel ini. Pak Mantri merupakan seorang lelaki tua yang menjabat sebagai Kepala Pasar di Pasar Kecamatan Gemolong dan lebih dikenal sebagai mantra pasar.

Dalam novel ini, Pak Mantri hidup sendiri di usianya yang tua dan salah satu hiburan bagi tokoh Pak Mantri adalah burung-burung peliharaannya, yang jumlahnya sangat banyak dan dibiarkan bebas beterbangan di sekitar pasar. Dalam menjalankan tugasnya, tokoh Pak Mantri dibantu oleh Paijo yang bertugas menarik karcis dari setiap pedagang yang berjualan di pasar itu, sekaligus merangkap sebagai tukang sapu pasar, dan juga mengurus burung-burung peliharaan tokoh Pak Mantri. Sebagai Mantri Pasar, pegawai pemerintah, ia berusaha menjalankan tugasnya dengan berlandaskan nilai-nilai Jawa dan kepercayaannya terhadap Tuhan yang diyakininya.

Hal ini terlihat pada sikapnya dalam menghadapi setiap persoalan dan juga pada petuah-petuahnya yang sering ia berikan kepada Paijo, tukang karcis pasar yang menjadi anak buahnya. Sebagai orang yang mempunyai jabatan, kadang tokoh Pak Mantri juga terlihat suka memerintah, juga mudah marah apabila yang diperintah tidak dapat menjalankan tugasnya dengan baik. Hal ini dia lakukan semata-mata rasa tanggung jawab terhadap tugas yang diamanatkan kepadanya.Berdasarkan uraian-uraian diatas kedua tokoh saling memiliki keinginan untuk mempertahankan diri dalam memimpin wilayah, sehingga para tokoh yang terdapat dalam novel Pasar karya kuntowijoyo memiliki strategi yang berdeba untuk menguasai pasar.Ajaran moral novel ini adalah keberanian moral untuk melihat diri sendiri, Sebaik-baik perbuatan ialah melihat diri sendiri dan dapat instrospeksi diri.

\section{REFERENSI}

Kuntowijoyo. (2017). Novel Pasar. Yogyakarta: Pustaka Pelajar.

Ratna,N.K. (2009). Teori,Metode, dan Teknik Penelitian Sastra . Yogyakarta: Pustaka Pelajar

Rohaniyah, Yoyoh. (2015). Pengantar Ilmu Politik (Kajian Mendasar Ilmu 
Wiwin Kurnia Widyanti: Represanti Dominasi Penguas dalam Novel PasarKarya Kuntowijoyo

Website : https://jurnal.umj.ac.id/index.php/penaliterasiEmail : penaliterasi@umj.ac.id

Politik). Malang, Jatim: Intrans

Publishing.

Ratna,N.K. (1990). Paradigma

SOSIOLOGI SASTRA. Denpasar:

Pustaka Pelajar Poedjawijatna.

(1986). Etika Filsafat Tingkah Laku.

Jakarta: PT. Bina Aksara.

Thoha, Mifta.(2014). Birokrasi \& Politik.

Jakarta.Rajawali Pers.

Budiananta, M.(1990). Teori Kesusastraan

(Buku Asli Theory of Literature)

Karya Rene Wellek dan Austin

Warren. Jakarta: Gramedia.

Santana,Septiawan.(2007). Menulis

Ilmiah Metode Penelitian

Kualitatif. Jakarta: Yayasan Obor

Indonesia

Siti Nuraini. HUBUNGAN KEKUASAAN

ELIT PEMERINTAHAN DESA.

Akses tanggal 5 Desember 2018.

http://download.garuda.ristekdikti.go.

id

Christy Damayanti. DIMENSI

KEKUASAAN DALAM EKONOMI:

Fakultas Ilmu Sosial dan Politik

Universitas Slamet Riyadi. Surakarta.

Akses tanggal 6 Desember 2018.

http://download.garuda.ristekdikti.go.

id. 